УДК 330.142.211

JEL: M11, G31

\author{
Хіоні Георгій Олександрович \\ аспірант відділу інвестиційного та матеріально-технічного забезпечення, \\ Національний науковий центр «Інститут аграрної економіки», \\ Київ, Україна \\ ORCID ID: 0000-0001-9952-1890 \\ e-mail:rmv.iae@gmail.com
}

\title{
УПРАВЛІННЯ МЕТОДИЧНИМИ ПІДХОДАМИ ДО ОЦІНОК ЕФЕКТИВНОСТІ ІНВЕСТИЦІЙ У МАЙНОВІ ОБ'СКТИ АГРОБІЗНЕСУ
}

Анотація. Здійснено аналіз факторів, що мають вплив на прийняття рішення щодо доцільності реалізації інвестиційного проєкту в агробізнесі. Запропоновані методичні підходи щодо оцінки потенціалу підприємств полягають у підготовці пропозицій власнику фінансово-нестабільного підприємства щодо його модернізації з метою підвищення ефективності його виробництва або щодо редевелопменту сільськогосподарської території чи невикористовуваного комплексу 3 метою подальшого продажу. Підготовка на замовлення власника інвестиційного проєкту щодо модернізації виробництва 3 метою залучення інвестицій $є$ однією з основних стадій даного методичного підходу. За результатами узагальнення методичних підходів до оцінки інвестицій, запропоновано при розробці та реалізації інвестиційних проектів виділяти дві основні групи факторів: 1) фактори, що впливають на підвищення окупності інвестиційного проекту $\rightarrow$ фактори економічної ефективності інвестиційних проектів; 2) фактори, що впливають на прийняття рішення інвесторів, щодо доцільності вкладення активів у даний проект $\rightarrow$ інвестиційні фактори, фактори інвестиційної привабливості. Дістало подальшого розвитку алгоритм управління методичними підходами щодо ефективності залучення інвестицій в майнові об'єкти агробізнесу, що складається з наступних етапів: оцінки наявного стану підприємства, об'єкту; розробки стратегії модернізації підприємства, об'єкта (побудова дорожньої карти); проведення бізнес-діагностики; розробки бізнес-плану з модернізації підприємства, об’єкта; прийняття рішення щодо реалізації проекту; реалізація проєкту. Запропоновані методичні підходи щодо оцінки потенціалу підприємств полягають у підготовці пропозицій власнику фінансово-нестабільного підприємства щодо його модернізації 3 метою підвищення ефективності його виробництва або щодо редевелопменту сільськогосподарської території чи невикористовуваного комплексу з метою подальшого продажу. Підготовка на замовлення власника бізнесплану щодо модернізації виробництва з метою залучення інвестицій є однією з основних стадій даного методичного підходу.

Ключові слова: управління інвестиційними проєктами; інвестиції; інвестиційний проєкт; інвестиційні фактори; ефективність інвестицій.

DOI: http://doi.org/10.32750/2020-0209

\section{ВСТУП}

Більшість сільськогосподарських товаровиробників здійснюють свою діяльність в умовах жорсткого дефіциту ресурсів. Неможливість своєчасного поповнення та оновлення ними основних засобів виробництва різко збільшують відповідальність при прийнятті рішень при формуванні, поповненні, оновленні та використанні виробничих потужностей підприємства. Більш того, необхідний індивідуальний підхід до проектування технічного оснащення конкретних об'єктів агробізнесу. При побудові системи показників економічної ефективності інвестицій на кожному рівні необхідно враховувати принципи всеосяжного відображення причинно-наслідкових зав'язків між витратами, що відображають використані ресурси виробництва і всі види інвестиційного ефекту.

Постановка проблеми. В умовах трансформації економічних відносин виникає безліч проблем, серед яких важливе місце займають проблеми інвестування сільського господарства. Умови ведення бізнесу на сільських територіях постійно змінюються. 
Тому суб'єкти підприємницької діяльності щороку вирішують питання щодо можливості розширення або скорочення масштабів бізнесу (обсягів виробництва продукції), що пов'язано відповідно з додатковими інвестиціями або вилученням капіталу. Без створення зацікавленості потенційних інвесторів у розширенні обсягів вкладень у вітчизняний аграрний сектор економіки в принципі неможливо вирішити завдання створення i збереження міцної матеріально технічної сільськогосподарських підприємств. У зв'язку з цим особливого значення набувають методи щодо управління ефективністю вкладень в інвестиційні проєкти.

Аналіз останніх досліджень і публікацій. Окремі питання організації, управління, фінансування, оцінки економічної ефективності інвестиційних проектів сільськогосподарських підприємств містяться у в наукових розробках українських вчених, а саме: В. Борисова, В. Васенка, А. Гайдуцького, О. Гальчинського, О. Гудзь, О. Гудзинського, І. Бланка, М. Дем'яненка, Т. Дудара, М. Кісіля [1], М. Корецького, С. Кравченка, О. Крисального, М. Кропивки, Г. Лайко, П. Макаренка, М. Маліка, Л. Михайлова, Г. Мостового, П. Саблука [3], О. Савченка, О. Олійника, В. Плаксієнка [2], О. Прокопенка, О. Скидана, Н. Сергєєвої [4], Н. Столярчук [7], В. Трегобчука, О. Тивончука, А. Чупіса, В. Юрчишина.

Мета статті - узагальнити методичні підходи до оцінок інвестицій у майнові об'єкти агробізнесу з метою прийняття ефективних управлінських рішень на етапі вибору та розробки інвестиційного проєкту.

\section{РЕЗУЛЬТАТИ ДОСЛІДЖЕННЯ}

Питання економічної ефективності при плануванні проектів розглядаються в різних масштабах та на різних стадіях планування. Відповідно розрізняють і методи, що застосовуються на окремих етапах планування та оцінки. На етапі проведення технічного аналізу та при плануванні фінансування проекту, коли відомі не всі умови підприємницької діяльності, вибір здійснюється на практиці за допомогою спрощеного часткового аналізу; на вирішальній стадії оцінки необхідно розглянути проект у цілому, беручи до уваги результати часткового аналізу, а потім прийняти позитивне або відхиляюче проект-рішення. Це здійснюється за допомогою глобальних моделей. Глобальними вони називаються тому, що дозволяють враховувати всі умови фінансової сфери. Ефективність проекту характеризується системою показників, які виражають співвідношення вигід і витрат проекту з погляду його учасників [6].

Використовувані в світовій практиці показники економічної ефективності інвестицій (чистий дисконтований дохід, внутрішня норма прибутковості, термін окупності проекту) в останні роки детально розглядаються як у вітчизняній літературі так і зарубіжній. Однак, слід зауважити, що застосування зазначених критеріїв для оцінки ефективності інвестиційних вкладень в сільське господарство з метою прийняття управлінських рішень стикається на практиці з певними труднощами.

Виділяють такі групи показники ефективності проекту:

- показники комерційної ефективності, які враховують фінансові наслідки реалізації проекту для його безпосередніх учасників;

- показники економічної ефективності, які враховують народногосподарські вигоди й витрати проекту, включаючи оцінку екологічних та соціальних наслідків, і допускають грошовий вимір;

- показники бюджетної ефективності, які відображають фінансові наслідки здійснення проекту для державного та місцевого бюджетів [5]. 
Розрізняють три основні методи визначення ефективності проектів на початкових етапах прийняття управлінських рішень щодо доцільності інвестування, які не враховують фактор часу або враховують його неповністю:

- порівняння витрат;

- порівняння прибутку;

- порівняння рентабельності, до якого належить як спеціальний випадок статистичний метод окупності (pay-back).

До найпростіших показників ефективності проектів, які застосовується при проведенні технічного аналізу відносять:

- капіталовіддачу (річні продажі, поділені на капітальні витрати);

- оборотність товарних запасів (річні продажі, поділені на середньорічний обсяг товарних запасів);

- продуктивність праці (річні продажі, поділені на середньорічну кількість зайнятих робітників і службовців).

Однак ці показники належать до числа показників моментного статичного ряду і не враховують динамічних процесів у їх взаємозв'язку.

Для оцінки ефективності проектів в модернізацію матеріально-технічної бази сільськогосподарських підприємств доцільніше використовувати показники, які дають змогу розрахувати значення критеріїв ефективності проектів, беручи до уваги комплексну оцінку вигід і витрат, зміну вартості грошей у часі та інші чинники. Правильне визначення обсягу початкових витрат на проект $є$ запорукою якості розрахунків окупності проекту.

На розмір і структуру інвестицій в модернізацію сільського господарства впливають такі групи чинників: кількісний і якісний склад технічних засобів (машиннотракторний парк), необхідний для здійснення процесу виробництва; сформований рівень цін на засоби механізації, площа земельних ділянок тощо.

На необхідний номенклатурний і кількісний склад техніки визначальний вплив мають природно-кліматичні, земельні, трудові та інші ресурси с.-г. товаровиробника, його регіональна приналежність, а також ряд організаційно-економічних чинників. Кожна природно-кліматична зона має цілком сформовані умови виробництва, що роблять істотний вплив на кількісний і якісний склад засобів механізації та, відповідно, формують потребу у інвестиціях. Щоб ефективно використовувати величезні капіталовкладення, необхідно виробляти їх обгрунтовано, з урахуванням конкретних умов господарювання та перспектив його розвитку.

М. І. Кісіль окремо виділяє ефективність використання ресурсів в аграрному виробництві за територіальними громадами і окремими сільськогосподарськими підприємствами [3]. Основними показниками, які потрібно взяти до уваги при прийнятті інвестиційного рішення в аграрному секторі $є$ : земельна площа, грошова нормативна оцінка сільськогосподарських земель, відповідність потреби в основних засобах нормативним вимогам; співвідношення оборотних засобів до основних; максимально можливим прогнозованим рівнем прибутку; різницю між прогнозованим і фактичним рівнем прибутку сільськогосподарського підприємства в даному регіоні; причини відхилення, можливості їх мінімізації; структура виробництва; напрямки підтримки інвестиційних проектів (будівництво, впровадження інновацій, технологічне оновлення) [3, с. 11].

Собівартість виступає одним із головних критеріїв, що впливає на прибуток, а відповідно і на економічну ефективність виробництва. Собівартість продукції як показник використовується для контролю за використанням ресурсів виробництва, визначення економічної ефективності організаційно-технічних заходів, встановлення 
цін на продукцію. За умов самофінансування зниження собівартості є основним джерелом зростання прибутку підприємства. При аналізі та оцінці ефективності формування витрат у сільському господарстві доцільно застосувати два підходи до структуризації витрат: за видами ресурсів і за статтями калькуляції.

В підтвердження даних слів В. Я. Плаксієнко наголошує «на потребі вивчення впливу співвідношення окремих елементів виробничих витрат на показники ефективності господарювання [2, с. 145-147]».

За дослідженнями Н. В. Сергєєвої «Вибір джерел фінансування - це наука, яка базується на мистецтві приймати інвестиційні рішення. У підприємницькій діяльності постійно доводиться вирішувати питання вигідності угоди, ефективності інвестування конкретного проєкту, які ведуть за собою витрату грошових коштів, а економічний ефект від цього буде отримано лише в перспективі. При цьому необхідно провести розрахунок із таким урахуванням ситуації, щоб вкладені суми відшкодували не тільки розмір понесених витрат, але й забезпечили певний рівень прибутковості проведених операцій» [4]. 3 точки зору залучення зовнішніх джерел фінансування важливу роль відіграють показники інвестиційної привабливості, що визначаються за аналізом фінансової звітності підприємства [7].

Поряд із загальними показниками ефективності використовують інші показники, їхні групи або системи, поглиблений (спеціальний) аналіз яких забезпечує прийняття обгрунтованих висновків і рішень. До таких спеціальних оцінок передусім належать системи показників для оцінювання фінансового стану підприємств та інвестиційних проектів, а також інвестиційних рішень, прибуток по яких відсутній або його неможливо визначити.

Окрім того, якщо суб'єкт агробізнесу реалізує інвестиційний проект, він має зробити його обгрунтування за методологією проектного аналізу, яка теж передбачає фінансову оцінку проекту.

У фінансовому аналізі інвестиційних проектів доходи і витрати приводять до теперішньої або майбутньої вартості, а також визначають: різницю між показниками приведених доходів і витрат (чисту приведену вартість), обсяги реалізації продукції, за яких доходи підприємства дорівнюють його витратам (точку беззбитковості), ставку дисконту, за якої сума продисконтованих вигод дорівнює сумі продисконтованих витрат (внутрішню норму рентабельності); норму прибутку, строк окупності проекту та інші показники [1].

У конкретних випадках сторона, яка оцінює економічну ефективність вкладень у агробізнес використовує показники ефективності, що найбільше відповідають іiі економічним інтересам та враховують вимоги критерію ефективності. Власники бізнесу i потенційні інвестори надають перевагу чистому прибутку, члени сільськогосподарському кооперативу - сумі прибутку і заробітної плати, органи державної влади й управління - прибутку до вирахування з нього податків, нарахувань i зборів. За результатами узагальнення методичних підходів управління оцінкою інвестицій, запропоновано при розробці та реалізації інвестиційних проектів виділяти дві основні групи факторів (таблиця 1):

1) що впливають на підвищення окупності інвестиційного проекту $\rightarrow$ фактори економічної ефективності інвестиційних проектів;

2) що впливають на прийняття рішення інвесторів, щодо доцільності вкладення активів у даний проект $\rightarrow$ інвестиційні фактори, фактори інвестиційної привабливості. 
Таблиця 1

Основні показники управління ефективністю інвестицій в майнові об'єкти агробізнесу

\begin{tabular}{|c|c|c|c|}
\hline № & Показник & Визначення & Складові \\
\hline 1 & 2 & 3 & 4 \\
\hline \multicolumn{4}{|c|}{ Фактори, що впливають на підвищення окупності інвестиційного проекту } \\
\hline 1 & $\begin{array}{l}\text { Ефективність } \\
\text { використання ресурсів в } \\
\text { аграрному виробництві за } \\
\text { територіальними } \\
\text { громадами і окремими } \\
\text { сільськогосподарськими } \\
\text { підприємствами }\end{array}$ & $\mathrm{E}_{\mathrm{p}}=\frac{\mathrm{B}_{\mathrm{H}}}{\mathrm{K}}=\frac{\Pi+\mathrm{A}+3_{\Pi}+\mathrm{O}_{3}+\mathrm{O}_{\mathrm{M}}+\mathrm{K}_{\phi 3}}{\mathrm{~K}_{3 \mathrm{~B}}+\mathrm{K}_{30}+\mathrm{K}_{\mathrm{oM}}+\mathrm{K}_{\mathrm{o \sigma}}+\mathrm{K}_{\text {л }}}$ & $\begin{array}{l}\text { Ерп - показник ефективності } \\
\text { ресурсів; Вн - новостворена } \\
\text { вартість; К - капітал; } \\
\text { П - прибуток; А - амортизація; } \\
\text { Зп - зарплата з нарахуваннями; } \\
\text { Оз - орендна плата за землю; } \\
\text { Ом - орендна плата за майно; } \\
\text { Кфз - сума плати за залучений } \\
\text { фінансовий капітал; Кзв і Кзо - } \\
\text { земля (власна і орендована); } \\
\text { Ком - майновий основний } \\
\text { капітал; Коб - оборотний } \\
\text { капітал; Кл - людський капітал. }\end{array}$ \\
\hline 2 & $\begin{array}{l}\text { Ефективність чистих } \\
\text { інвестицій } \\
\text { Строк окупності } \\
\text { інвестицій відповідно }\end{array}$ & $\mathrm{Ei}=\left(\mathrm{BH}_{2}-\mathrm{BH}_{1}\right):(\mathrm{Iв} 2-\mathrm{A} 2)=\Delta \mathrm{BH}: \mathrm{Iч}$ & $\begin{array}{l}\text { Ів, Іч - інвестиції валові та } \\
\text { чисті; } \\
\Delta \text { - приріст значень } \\
\text { відповідного показника }\end{array}$ \\
\hline 3 & $\begin{array}{l}\text { Граничний } \\
\text { маржинальний дохід }\end{array}$ & Дг $=\frac{\Delta Д}{\Delta \mathrm{P} n}$ & $\begin{array}{l}\Delta Д-\text { обсяг приросту загального } \\
\text { доходу; } \\
\Delta \mathrm{Pn}-\text { зміна масштабу випуску } \\
\text { продукції }\end{array}$ \\
\hline 4 & $\begin{array}{l}\text { Показник граничних } \\
\text { (маржинальних) витрат }\end{array}$ & $\mathrm{B} \Gamma=\frac{\Delta \mathrm{B}}{\Delta \mathrm{P}}$ & $\begin{array}{l}\Delta \mathrm{B} \text { - зміна загальних витрат } \\
\Delta \mathrm{P} \text { - зміна обсягу випуску } \\
\text { продукції }\end{array}$ \\
\hline 5 & $\begin{array}{l}\text { Норма прибутку на } \\
\text { капітал }\end{array}$ & Рок $=\frac{\text { ПК }}{\kappa \times 100}$ & $\begin{array}{l}\text { Пк - прибуток на капітал } \\
\text { К - функціонуючий капітал }\end{array}$ \\
\hline 6 & $\begin{array}{l}\text { Рентабельність } \\
\text { виробництва }\end{array}$ & $\mathrm{P}=\frac{\Pi}{\mathrm{C}} \times 100 \%$ & $\begin{array}{l}\text { П - прибуток; } \\
\text { С - собівартість }\end{array}$ \\
\hline 7 & $\begin{array}{l}\text { Показник } \\
\text { макроекономічної } \\
\text { ефективності }\end{array}$ & 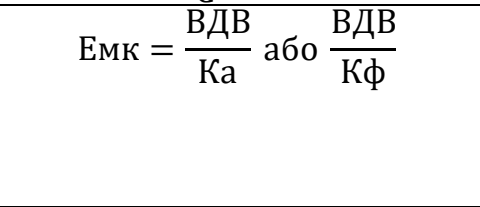 & $\begin{array}{l}\text { ВДВ - валова додана вартість; } \\
\text { Ка - вартість авансованого } \\
\text { капіталу; } \\
\text { Кф - вартість функціонуючого } \\
\text { капіталу }\end{array}$ \\
\hline 8 & $\begin{array}{l}\text { Показник окупності } \\
\text { iнвестицій приростом } \\
\text { ефекту }\end{array}$ & Eмі $=\frac{\Delta \text { ВДВ }}{\text { I }}$ & $\begin{array}{l}\Delta \text { ВДВ - приріст валової доданої } \\
\text { вартості; } \\
\text { I - сума інвестицій за звітний } \\
\text { період }\end{array}$ \\
\hline \multicolumn{4}{|c|}{$\begin{array}{c}\text { Фактори, що впливають на прийняття рішення інвесторів, щодо доцільності вкладення активів у даний } \\
\text { проект (фактори інвестиційної привабливості) }\end{array}$} \\
\hline 9 & Собівартість виробництва & $\mathrm{C}_{\mathrm{B}}=\mathrm{BмaT}+\mathrm{B}_{3}+\mathrm{BiH}+3 \mathrm{BB}$ & $\begin{array}{l}\text { Вмат - прямі матеріальні } \\
\text { витрати; } \\
\text { Взп - прямі витрати на оплату } \\
\text { праці; } \\
\text { Він - інші прямі витрати; } \\
\text { ЗВВ - загальновиробничі } \\
\text { витрати }\end{array}$ \\
\hline 10 & Урожайність & У=Валовий збір / Площа & $\begin{array}{l}\text { Валовий збір - валовий збір з } \\
\text { основних, повторних і } \\
\text { міжрядних посівів, ц; }\end{array}$ \\
\hline
\end{tabular}




\begin{tabular}{|c|c|c|c|}
\hline & & & $\begin{array}{l}\text { Площа - фактично зібрана } \\
\text { площа, га; }\end{array}$ \\
\hline 11 & Продуктивність & $\mathrm{W}=\mathrm{Q} / \mathrm{T}$ & $\begin{array}{l}\text { Q - кількість виробленої } \\
\text { продукції; } \\
\text { Т - витрати праці }\end{array}$ \\
\hline 12 & Трудомісткість & $t=T / Q$ & $\begin{array}{l}\text { Q - кількість виробленої } \\
\text { продукції; } \\
\text { T - витрати праці }\end{array}$ \\
\hline 13 & Приріст виробництва & Дкв $=\frac{\mathrm{OB} 1}{\mathrm{C} 1}-\frac{\mathrm{OB}}{\mathrm{C} 0}$ & $\begin{array}{l}\text { Зміна обсягу виробництва у } \\
\text { звітному році (OB1) порівняно } \\
\text { з попереднім роком (OB0) } 3 \\
\text { розрахунку на одиницю витрат } \\
\text { у звітному (C1) і базовому (C0) } \\
\text { в періодах }\end{array}$ \\
\hline 14 & Темп приросту & $\mathrm{T} \Pi=\frac{\text { Двк } \times \mathrm{C} 1}{\text { оВ0 }} \times 100 \%$ & $\begin{array}{l}\text { Відсоткове відношення } \\
\text { приросту обсягу виробництва } \\
\text { на одиниці витрат ( } \Delta \text { вк) у } \\
\text { звітному році порівняно з } \\
\text { базовим до рівня виробництва } \\
\text { на одиницю витрат у } \\
\text { попередньому періоді }\end{array}$ \\
\hline 15 & Структура посівних площ & $\Pi_{\Pi}=\left(П-Ф_{\mathrm{H}}\right) /(\mathrm{Y}-\mathrm{Hв})$ & $\begin{array}{l}\text { П - потреба продукції } \\
\text { рослинництва; } \\
\text { Фн - фонд насіння, ц; } \\
\text { У - урожайність, ц/га; } \\
\text { Нв - норма висіву, ц/га }\end{array}$ \\
\hline 16 & Матеріаломісткість & $\mathrm{Mo}=\mathrm{V} / \mathrm{M}$ & $\begin{array}{l}\text { V - обсяг реалізованої } \\
\text { продукції; } \\
\text { M - матеріальні витрати }\end{array}$ \\
\hline 17 & Матеріаловіддача & $\mathrm{Me}=\mathrm{M} / \mathrm{V}$ & $\begin{array}{l}\text { V - обсяг реалізованої } \\
\text { продукції; } \\
\text { М - матеріальні витрати }\end{array}$ \\
\hline 18 & Фондозабезпеченість & $\Phi_{3}=$ Boc. $\phi / \Pi * 100$ & $\begin{array}{l}\text { Вос.ф-вартість основних } \\
\text { фондів сільськогосподарського } \\
\text { призначення, грн.; } \\
\text { П - площа } \\
\text { сільськогосподарських угідь, га }\end{array}$ \\
\hline 19 & Фондоозброєність & $\Phi{ }^{\prime} 3=$ Boc.. $/ K$ & $\begin{array}{l}\text { К - середньорічна чисельність } \\
\text { працівників }\end{array}$ \\
\hline 20 & Фондовіддача & Фвід= Вв.п. / Во.ф & $\begin{array}{l}\text { Вв.п - вартість валової } \\
\text { продукції, грн. }\end{array}$ \\
\hline 21 & Фондомісткість & Фміст=Во.ф/Вв.п & $\begin{array}{l}\text { Вв.п - вартість валової } \\
\text { продукції, грн }\end{array}$ \\
\hline
\end{tabular}

3 метою визначення перспективи вкладення інвестицій здійснюють оцінку потенціалу підприємства. В основу такої оцінки покладено відтворювальний підхід, який передбачає аналіз ресурсного, витратного i результатного станів суб'єкта господарювання. Все це дозволяє отримати інформацію про підсумки господарської діяльності підприємства, виявити резерви, оцінити шляхи можливого підвищення результативності функціонування підприємницької структури 3 метою прийняття ефективних управлінських рішень.

Враховуючи вищенаведену інформацію, нами запропоновано методичні підходи щодо оцінки потенціалу підприємств, що передбачають (рис. 1): 


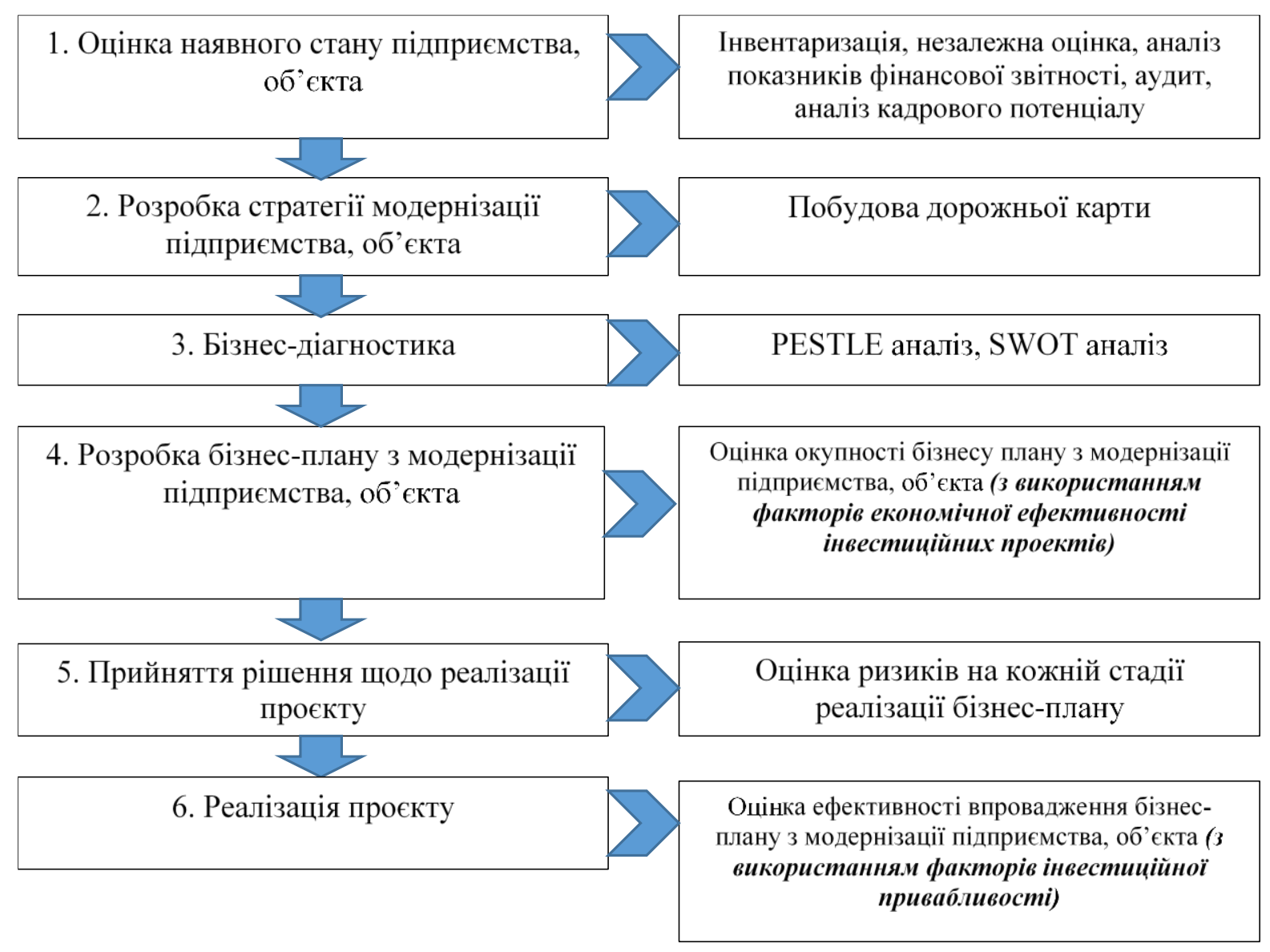

Рис. 1. Алгоритм управління методичними підходами щодо ефективності залучення інвестицій в майнові об’єкти агробізнесу

1. Оцінку наявного стану підприємства, об’єкту Для прийняття інвестиційних рішень інвестор використовує інформацію про фінансовий стан та результати діяльності підприємства, що міститься у фінансовій звітності за останні 3-5 років. Однак, цієї інформації може бути у більшості випадків недостатньо для виявлення всіх можливих ризиків, аналізу господарської діяльності підприємства, його фінансових і операційних показників, оцінки становища підприємства на ринку того чи іншого виду продукції, робіт (послуг) та визначення чітких планів майбутнього розвитку. Полягає у проведенні таких процедур як інвентаризація, незалежна оцінка, аналіз показників фінансової звітності, аудит, аналіз кадрового потенціалу, з метою оцінки фактичної ситуації на даний момент.

2. Розробка стратегії модернізації підприємства, об'єкта (побудова дорожньої карти). Одним із етапів формування інвестиційної стратегії є складання стратегічної карти, яка враховуватиме різні варіанти перебігу реалізації проєкту та може бути базисом для формування та коригування наступних подальших дій промислових підприємств. Необхідним на цьому етапі $\epsilon$ проведення порівняння план-факту за значеннями напрацьованих показників із з'ясуванням причин відхилень. Такий аналіз супроводжується або коректуванням цільового значення показника, або розробкою коригувальних заходів, спрямованих на досягнення встановленого раніше цільового значення.

3. Проведення бізнес-діагностики. Фактично є одним із методів стратегічного планування. Комплексна діагностика включає наступні види аналізу i оцінок: 
ситуаційний аналіз; організаційно-управлінський аналіз; фінансово-економічний аналіз; виробничо-господарський аналіз; аналіз кадрового потенціалу; оцінку бізнесу i підприємства. Ситуаційний аналіз призначений для визначення ситуації, в якій знаходиться підприємство, тобто місця, яке воно займає в загальному бізнес-просторі, основних факторів, що впливають на функціонування підприємства, а також його укрупнених характеристик в цілому. PESTLE аналіз, SWOT аналіз є основними методами ситуаційного аналізу.

4. Розробка бізнес-плану з модернізації підприємства, об’єкта. Бізнес-план - це докладний, чітко структурований і ретельно підготовлений документ, що описує, до чого прагне фірма, як вона припускає домогтися поставлених цілей і як буде виглядати після ïx досягнення. Це зручна, загальноприйнята форма ознайомлення потенційних інвесторів 3 проектом, в якому їм пропонується взяти участь. Бізнес-план має включати в себе наступні розділи: можливості фірми (резюме); види товарів (послуг); ринки збуту товарів (послуг); конкуренція на ринках збуту; план маркетингу; організаційний план, фінансовий план; правове забезпечення діяльності; оцінка ризику і страхування; програми. Актуальність розробки бізнес-планів для сучасних підприємств полягає в тому, що він здатний переконати сторонніх інвесторів у доцільності вкладання грошей в бізнес, а також допомагає зберегти обраний курс діяльності. Під час розробки бізнесплану важливою є оцінка окупності бізнесу плану з модернізації підприємства, об'єкта (з використанням факторів економічної ефективності інвестиційних проектів). Вибір конкретного критерію для висновку про ефективність проекту залежить від різноманітних чинників - наявної ринкової перспективи, існування обмежень на ресурси для фінансування проєкту, коливань грошових потоків, можливості одержання прибутку тощо. Так, у випадку разових капітальних вкладень, а також потоку різночасних однакових надходжень оцінювання ефективності інвестицій доцільно проводити за допомогою визначення терміну їх окупності з урахуванням фактору часу.

5. Прийняття рішення щодо реалізації проекту. Вибір відповідного рішення передбачає розробку критеріїв (контрольних показників) оцінки альтернатив, оцінку i вибір кращої альтернативи. Тут найбільш відповідальна операція - розробка критеріїв оцінки альтернатив. Основні критерії оцінки задані обмеженнями проекту - за термінами, бюджету і параметрам якості виконання роботи. Ці критерії зазвичай носять загальний характер і для їх перегляду потрібні дуже серйозні причини. Інші критерії встановлюються найчастіше ситуаційно, залежно від гостроти проблеми, можливих негативних наслідків несвоєчасного ії вирішення, залежно від іiі рішення виконання робіт проекту і багато чого іншого. Оцінка ризиків на кожній стадії реалізації інвестиційного проєкту здійснюється за допомогою одного з методів (метод чутливості, метод сценаріїв, метод Монте-Карло, тощо). При прогнозуванні можливих ризиків необхідно користуватися прогнозними оцінками, які стосуються обсягів продажу, майбутньої частки ринку, розвитку регіону, галузі і навіть окремої країни. Основними видами ризиків є: виробничий ризик (пов'язаний 3 можливістю невиконання підприємством своїх обов'язків за контрактом чи договором з замовником); фінансовий (кредитний) ризик (пов'язаний 3 можливістю невиконання підприємством своїх фінансових зобов'язань перед інвестором (кредитором); інвестиційний ризик (пов'язаний 3 можливим знеціненням інвестиційно-фінансового портфеля); ринковий ризик (пов'язаний із можливим коливанням процентних ставок як у гривнях, так і в курсах іноземних валют).

6. Реалізація проєкту. На даній стадії відбувається фінансування і безпосередньо реалізація самого проєкту. Проводиться оцінка ефективності впровадження бізнес-плану 3 модернізації підприємства, об'єкта (3 використанням факторів інвестиційної 
привабливості). Оцінка ефективності інвестиційних проектів повинна враховувати не лише економічні результати, а й екологічні та соціальні. Оскільки лише тоді інвестиційний проект є високоефективним та привабливим.

Отже, при виборі варіантів методики оцінки економічного потенціалу сільськогосподарського підприємства слід виходити 3 цілей зазначеної оцінки. Переважно зазначена оцінка внутрішніх можливостей підприємства цікавить його власників та інвесторів, в зв'язку з цим в якості основних критеріїв оцінки можуть бути використані критерій чистої поточної вартості або сталий критерій прибутку.

\section{ВИСНОВКИ ТА ПЕРСПЕКТИВИ ПОДАЛЬШИХ ДОСЛІДЖЕНЬ}

Запропоновані методичні підходи щодо оцінки потенціалу підприємств полягають у підготовці пропозицій власнику фінансово-нестабільного підприємства щодо його модернізації з метою підвищення ефективності. Підготовка на замовлення власника інвестиційного проєкту щодо модернізації виробництва з метою залучення інвестицій $€$ однією з основних стадій даного методичного підходу. В результаті проведеного дослідження розроблено алгоритм управління методичними підходами щодо ефективності залучення інвестицій в майнові об'єкти агробізнесу з метою підвищення ефективності використання ресурсного потенціалу на основі оцінки окупності бізнесу плану з модернізації підприємства, об'єкта (з використанням факторів економічної ефективності інвестиційних проектів) та оцінки ефективності впровадження бізнесплану з модернізації підприємства, об'єкта (з використанням факторів інвестиційної привабливості).

\section{СПИСОК ВИКОРИСТАНИХ ДЖЕРЕЛ}

1. Кісіль М. І. Теоретико-методологічні засади оцінок ефективності агробізнесу. Київ. ННЦ «IAЕ». 2015. $36 \mathrm{c}$.

2. Плаксієнко В. Я. Виробничі витрати та доходи сільського господарства в умовах розвитку ринкових відносин. Дніпропетровськ. Січ. 1997. 255 с.

3. Рекомендації з розроблення Дорожньої інвестиційної карти розвитку аграрного району: за ред. Я. М. Гадзала, П. Т. Саблука. Київ. Аграр. наука, 2017. 148 с.

4. Sergeyeva N. V., Stolarchuk N. M., Danylenko V. V., Zhang Hong. Improvement of methodological approaches to accounting for sources of financing of capital investments with reference of Ukraine. International journal of scientific \& technology research. 2020. № (9)2. P. 5316-5320. Scopus:http://www.ijstr.org/paperreferences.php?ref=IJSTR-0220-30404.

5. Тян Р. Б. Управління проектами: навч. посібн. Дніпропетровськ: Дніпропетровська академія управл., бізнесу та права, 2000. $224 \mathrm{c}$.

6. Фунтов В. Н. Передумови успішної реалізації проектів розвитку підприємства: теорія і практика. СПб.: Питер, 2009. 496 с.

7. Yuriy Kyrylov, Nadiia Stoliarchuk, Iryna Sadovska, Andrii Bilochenko, Alina Matviienko, Heorhii Khioni. Innovation as an important production factor and a factor in increasing the investment attractiveness of the agricultural sector. Management Theory and Studies for Rural Business and Infrastructure Development. eISSN 2345-0355. 2020. Vol. 42. No. 4: 458-465. Article DOI: https://doi.org/10.15544/mts.2020.47. 


\author{
Хиони Георгий Александрович \\ аспирант отдела инвестиционного и материально-технического обеспечения \\ Национальный научный центр «Институт аграрной экономики», \\ Киев, Украина \\ ORCID ID: 0000-0001-9952-1890 \\ e-mail:rmv.iae@gmail.com
}

\title{
УПРАВЛЕНИЕ МЕТОДИЧЕСКИМИ ПОДХОДАМИ К ОЦЕНКАМ ЭФФЕКТИВНОСТИ ИНВЕСТИЦИЙ В ИМУЩЕСТВЕННЫЕ ОБЪЕКТЫ АГРОБИЗНЕСА
}

Аннотация. Осуществлен анализ факторов, влияющих на принятие решения о целесообразности реализации инвестиционного проекта в агробизнесе. Предложенные методические подходы к оценке потенциала предприятий заключаются в подготовке предложений владельцу финансово-нестабильного предприятия по его модернизации с целью повышения эффективности его производства или касательно редевелопмента сельскохозяйственной территории или неиспользуемого комплекса с целью дальнейшей продажи. Подготовка по заказу владельца инвестиционного проекта модернизации производства с целью привлечения инвестиций является одной из основных стадий данного методического подхода. По результатам обобщения методических подходов к оценке инвестиций, предложено при разработке и реализации инвестиционных проектов выделять две основные группы факторов: 1) факторы, влияющие на повышение окупаемости инвестиционного проекта $\rightarrow$ факторы экономической эффективности инвестиционных проектов; 2) факторы, влияющие на принятие решения инвесторов относительно целесообразности вложения активов в данный проект $\rightarrow$ инвестиционные факторы, факторы инвестиционной привлекательности. Получило дальнейшего развития алгоритм управления методическими подходами к эффективности привлечения инвестиций в имущественные объекты агробизнеса, состоящий из следующих этапов: оценки существующего положения предприятия, объекта; разработки стратегии модернизации предприятия, объекта (построение дорожной карты) проведение бизнес-диагностики; разработки бизнес-плана по модернизации предприятия, объекта; принятие решения о реализации проекта; реализация самого проекта. Предложенные методические подходы к оценке потенциала предприятий заключаются в подготовке предложений владельцу финансово-нестабильного предприятия его модернизации с целью повышения эффективности его производства или редевелопмента сельскохозяйственной территории или неиспользуемого комплекса с целью дальнейшей продажи. Подготовка по заказу владельца бизнес-плана по модернизации производства с целью привлечения инвестиций является одной из основных стадий данного методического подхода.

Ключевые слова: управление инвестиционными проектами; инвестиции; инвестиционный проект; инвестиционные факторы; эффективность инвестиций. 


\author{
Georgii Khioni \\ postgraduate student of the department of investment and material and technical support \\ National Scientific Centre "Institute of Agrarian Economics", \\ Kyiv, Ukraine \\ ORCID ID: 0000-0001-9952-1890 \\ e-mail:rmv.iae@gmail.com
}

\title{
MANAGEMENT OF METHODICAL APPROACHES TO EVALUATIONS OF EFFICIENCY OF INVESTMENT IN AGRICULTURAL PROPERTIES
}

Abstract. An analysis of the factors that influence the decision on the feasibility of implementing an investment project in agribusiness. The proposed methodological approaches to assess the potential of enterprises are to prepare proposals for the owner of a financially unstable enterprise to modernize it by increasing the efficiency of its production or to redevelopment of agricultural land or unused complex from resale. Preparation of the order of the owner of the investment project for the modernization of production by reducing investment is one of the main stages of this methodological approach. Based on the results of generalization of methodological approaches to investment evaluation, it is proposed to identify two main groups of factors in the development and implementation of investment projects: 1) factors influencing the increase of the investment project $\rightarrow$ factors of economic efficiency of investment projects; 2) factors influencing the decision-making by investors on the feasibility of investing assets in this project $\rightarrow$ investment factors, factors of investment attractiveness. Received further development of the algorithm for managing methodological approaches to the effectiveness of attracting investment in property of agribusiness, consisting of the following stages: assessment of the current state of the enterprise, object; development of strategies for modernization of the enterprise, object (construction of a road map); conducting business diagnostics; development of a business plan for the modernization of the enterprise, object; decision-making on project implementation; project implementation. The proposed methodological approaches to assess the potential of enterprises are to prepare proposals for the owner of a financially unstable enterprise to modernize it by increasing the efficiency of its production or to redevelopment of agricultural land or unused complex for resale. Preparation of the order of the owner of the business plan for the modernization of production by attracting investment is one of the main stages of this methodological approach.

Keywords: investment project management; investments; investment project; investment factors; investment efficiency.

\section{REFERENCES}

1. Kisil, M. I. (2015). Theoretical and methodological principles of assessing the effectiveness of agribusiness. Kiev. NSC "IAE". [in Ukrainian].

2. Plaksienko, V. Y. (1997). Production costs and incomes of agriculture in the development of market relations. Dnipropetrovsk. Jan. 255 [in Ukrainian].

3. Recommendations for the development of the Road Investment Map of the development of the agricultural area: ed. J. M. Gadzalo, P. T. Sabluk. (2017). Kiev. Agrarian. Science. 148 [in Ukrainian].

4. Sergeyeva N. V., Stolarchuk N. M., Danylenko V. V., Zhang Hong. (2020). Improvement of methodological approaches to accounting for sources of financing of capital investments with reference of Ukraine. International journal of scientific \& technology research. № (9)2. P. 5316-5320. Scopus:http://www.ijstr.org/paper-references.php?ref=IJSTR-0220-30404. [in English].

5. Tyan R. B. (2000). Project management: textbook. manual Dnipropetrovsk: Dnipropetrovsk Academy of Management, Business and Law. 224 p. [in Ukrainian].

6. Pounds V. N. (2009) Prerequisites for successful implementation of enterprise development projects: theory and practice. $\mathrm{SPb}$.: Piter. 496. [in Russian].

7. Yuriy Kyrylov, Nadiia Stoliarchuk, Iryna Sadovska, Andrii Bilochenko, Alina Matviienko, Heorhii Khioni. (2020). Innovation as an important production factor and a factor in increasing the investment attractiveness of the agricultural sector. Management Theory and Studies for Rural Business and Infrastructure Development. eISSN 2345-0355. Vol. 42. No. 4: 458-465. Article DOI: https://doi.org/10.15544/mts.2020.47. [in Ukrainian]. 